\title{
The Italian Canon Abroad
}

\author{
Amilcare A. Iannucci \\ University of Toronto
}

\begin{abstract}
Literary canons, or lists of authorial books, have come under heavy fire recently, but, in spite of this, they continue to exist and to thrive. O ne such canon is the Italian canon abroad, that is, that list of Italian authors who have emerged as authoritative figures in the literature, culture and education of non-Italian speaking peoples of the twentieth century. This paper focuses on this canon, its historical evolution and the gradual inclusion in it of its constituent members, namely, D ante, Petrarch, Boccaccio, Ariosto, Tasso, M achiavelli, Vico and Pirandello. The dominance of these authors abroad is explored from their preeminence in educational curricula, translations, and serious engagement by non-Italian writers.
\end{abstract}

The canon «controversy is one of the more important events in the history of twentieth-century criticism ${ }_{1}^{1}$ as a recent special edition of Allegoria amply bear witness. ${ }^{2}$ D erived from a G reek word, meaning «rod»or «rule», the word canon was originally applied to religious works such as the books of the Bible and signified a list of works which were considered orthodox, authentic, authoritative and so worthy of preservation. The word was extended to literary works in the eighteenth century. ${ }^{3}$ Since that time the Western canon (and, by derivation, all national canons) ${ }^{4}$ denotes a list of authorial, «quasi-sacred G reat

1. John GUILLORY, «C anon», Critical Terms for Literary Study, ed. Frank Lentricchia and Thomas M CLaughlin, Chicago: University of Chicago Press, 1990, p. 233-249: 234.

2. The edition (n. 29-30, 1998) contains a wide range of material including formative articles on problems associated with the canon (Remo CESERANI, «Appunti sul problema dei canoni», p. 58-74), the role of the reader in canon formation (H ans Robert J AusS, «l lettore come istanza di una nuova storia della letteratura», p. 23-41) and the canon within and outside of Italy (Andrea BAT TISTIN I, «II canone in Italia e fuori d'Italia», p. 42-57), These articles and others will be cited in subsequent footnotes.

3. C fr. H arold BLO o m, The Western Canon: The Books and School of the Ages, N ew York: H arcourt Brace \& C 0., 1994, p. 20.

4. Canons can be represented in multiple different ways, from genre (poetry versus prose), through period (the Renaissance canon versus the Enlightenment canon) to geography. 
Books $\gg,{ }^{5}$ which have been ranked as the very best, so to speak, and which have been selected for the purposes of literary emulation and pedagogic inculcation.

Recently the literary canon has come under heavy fire. This attack has been mounted from several different quarters. First, literary critics of the school of post-structuralism, and its literary disciple, deconstructionism, who have been reared on Foucaltian, D erridean and Lacanian readings of a text and who stress the instability and indeterminancy of meaning, are opposed to anything fixed or static. They thus denounce any system that claims to have universal validity and regard the canonization of any text as encompassing universal truth to be spurious, at best, futile, at worst, another example of literary total itarianism. It is precisely this very questioning, by the new literary critics, of universal truth, and its emphasis on the relativism of any text, that has afforded many others «the interpretive framework for challenging the canon». ${ }^{6}$ Secondly, special interest groups, such as feminists, ethnicists and homosexuals, take issue with the canon's formation and meaning. They see the process of its evoIution as having been historically, and therefore essentially, determined by white, heterosexual, colonizing males. As Paul Lauter argues, the canon «is, in short, a means by which culture validates social power». ${ }^{7}$ Thus, feminist lite-

Taking the latter, it is interesting to note that even within canons, arranged nationally, regional canons can and do abound. For a fascinating study of this phenomenon, especially as it relates to the dialect canons of Italy, see Hermann W. H ALLER, The O ther I taly. The Literary Canon in D ialect, Toronto: University of Toronto Press, 1999.

5. Sandra M. GILBERT, «Shadows of Futurity: The Literary Imagination, the M LA, and the Twenty-First Century», PM LA, n. 112, 1997, p. 370-379: 375. The notion of the canon as authoritative, definitive and binding is contained in most of the standard literary dictionaries (see, for example, J. A. C UDD ON, The Penguin D ictionary of Literary Terms and Literary Theory, H armondsworth, Penguin, 1991). Lurking behind any definition of canon are two distinct notions, one which view the canon from the perspective of the works themselves and their influence, the other which views the canon from the perspective of the reader and the general public (for observations on both notions, see Romano LUPERIN I, «D ue nozioni di canone», Allegoria, n. 29-30, p. 5-7). Similary distinctive are the two etymologies for canon, namely, a rule or a measuring standard and a catalogue or a list (see Remo CESERAN I, op. cit., p. 58). Both notions and both etymologies hace to be borne closely in mind in any discussion of the canon.

6. James ATLAS, Battle of the Books. TheC urriculum D ebate in America, N ew York: W. W. Norton, 1993, p. 66.

7. Paul LAUTER, «Race and Gender in the Shaping of the American Literary Canon», Feminist Studies, n. 9, 1983, p. 435-463: 435. The interpretation of canon formation as a reflection of an existing power structure has been much in vogue. It is evident, for example, in one of the first works to deal with this subject, The Politics of Literature, by Louis KAM PF and Paul LAUTER (N ew York: Pantheon, 1972), which arose out of the observation that «high culture propagates the values of those who rule and therefore helps to maintain current social arrangementss (p. 8). At times it is more radically stated, as when it is joined to a $M$ arxist critique, according to wich, as Richard O H M AN N, T hePolitics of Letters, M iddletown, Conn.: Wesleyan University Press, 1987, p. 3 ff., argues, teachers of English have become servants of monopoly capitalism. Thus, according to its critics, the canon is justified by the very values we bring to the enterprise of its formation, not only historical and political values, but literary and critical values as well, the latter point underscored by Frank H ERM ODE, «nstitutional C ontrol of 
rary critic Jane Tompkins, in arguing that there is a dynamic interplay between the changing currents of social and political life and the establishment of great literature, accounts for the canonical non-status of $\mathrm{H}$ arriet Beecher Stowe's U ncle Tom's C abin and Susan Warner's TheW ide, Wide World thusly: «because they were written by, about, and for women, they have been excluded from the literary canon ${ }^{8}{ }^{8}$ These groups therefore eschew the canon as representative of vested interests and want to open it up. In its stead they accordingly propose literary alternatives which emphasize gender and sexual difference, a «defamilarization of masculinity, a poetics of the 0 ther $\gg,{ }^{9}$ and the history and literature of disfranchised minority groups such as Afro-Americans and representatives of the Third World. ${ }^{10}$ Thirdly, both academics and students alike have questioned the pedagogic centrality of the canon. For the canon has not only been used to shape the core curriculum of educational offerings at every institutional level, but has also permeated traditional pedagogic offerings, such as souce books, histories, collections, anthologies and various other texts dealing with thought and culture. Thus the canon with its choice of select authors has greatly determined the education program and it is this exclusivity of cer-

Interpretation», Salmagundi, n. 43, 1979, p. 72-86. In this enterprise the position and importance of minority cultures and positions has assumed major significance. H enry Louis G ATES $J R$. reviews many of these and their position of marginality in the canon in Loose Canons, N otes on the Culture Wars, O xford: O xford University Press, 1992, p. $17 \mathrm{ff}$. In place of their ostracism from the canon, G ATES argues for their inclusion. Thus, in dealing with the African American tradition, G ATES, while not denying the «politics and ironies of canon formation» (p. 32) neverthel ess attempts to elaborate a canon that is reflective of this tradition, that is, "our" canon, one possible set of selections among several possible sets of selections» (p. 32), a task which he brings to fruition in his later The N orton Anthology of African American Literature, N ew York: W. W. N orton, 1997. In a similar vein, but much more broad in scope, is the attempt of Linda H UTCHEON, M ario VALDÉS and others to rethink literary history comparatively from the position of the marginalized, and enterprise which «seeks not only to address specific instances of historical exclusions and inclusions, but to rethink the very categories of selection and ordering used in the writing of literary history» (M ario J. VALDÉS and Linda H UTCHEON, «Rethinking Literary H istory Comparatively», American Council of L earned Societies, 0 ccasional Paper, n. 27, 1994, p. 1-13: 11.

8. JaneP. TOM PKIN S, Sensational D esigns: The Cultural Work of American Fiction, 1790-1860, N ew York: Oxford University Press, 1985, p. 192-193 and p. 120.

9. James ATLAS, op. cit., p. 63. Indicative of this approach is the collection of essays by Leslie A. FIED LER and H ouston A. BAKER, JR., English Literature, O pening U p the C anon, Baltimore: The Jhons H opkins U niversity Press, 1981, and the series of reflections by Lawrence W. LEVINE, The O pening of the American M ind, Canons, Culture, and H istory, Boston: Beacon Press, 1996.

10. For African American studies, in addition to the works of $G$ ATES cited above, see H ouston A. BAKER, JR., English in the Criticism of African, Caribbean, and Black American Literature, Ithaca: N . Y., Africana Studies and Research Center, Cornell University, 1976. For an introduction to feminism and literary studies, see, Gayle G ReEn E and Coppélia KAH N, M aking a D ifference: Femminist Literary Criticism, London: M ethuen, 1985. For the burgeoning field of post-colonial studies, especially its philosophical and intellectual context and major areas of concern, see Leela G H AN D I, Postcol onial Theory. A C ritical Introduction, N ew York: Columbia, 1998. 
tain writers and their works that critics of the canon question. They view the canon in a hostile way as static and outmoded, an exclusivist or closed system which runs counter to the inclusive (that is, no longer Anglo-Saxon dominated) university environments of the present day and the freedoms of expression and educational choice which they have fought for and won since the turbulent days of academic protest and unrest of the 1960s. They therefore maintain that the canon's major deficiency is one of limitation, limitation of historical growth, and limitation of inclusion. Thus, «those who endorse a core curriculum, a canon of great works, are old-fashioned. To claim that such a canon exists is to discriminate against the literature of minorities. To teach the canon is to ignore the ethnic diversity of college students in the $1990 \mathrm{~s} » .{ }_{11}^{11}$

A number of canon defenders have marshaled themselves against these broadsides. Allan Bloom for example, in his runaway best seller, The Closing of the American M ind, surveyed contemporary American education and culture and lambasted its deplorable absence of literary values. Taking aim at what he perceived to be its underlying cause, namely, deconstructionist critics and their attacks on established literary works, Bloom writes as follows:

The school is D econstructionism, and it is the last, predictable, stage in the suppression of reason and the denial of the possibility of truth in the name of philosophy. The interpreter's creative activity is more important than the text; there is no text, only interpretation. Thus the one thing most necessary for us, the knowledge of what these texts have to tell us, is turned over to the subjective, creative selves of these interpreters, who say that there is both no text and no reality to which the texts refer. A cheapened interpretation of $\mathrm{N}$ ietzsche liberates us from the objective imperatives of the texts that might have liberated us from our increasingly low and narrow horizon. Everything has tended to soften the demands made on us by the tradition; this simply desolves it. ${ }^{12}$

In similar vein, $\mathrm{H}$ arold Bloom, in The Western Canon, has castigated the assault on the established canon and excoriated those special interest groups who propose «opening up» the canon and establishing al ternatives by its side. Bloom lumps all of these groups together and disrespectfully refers to them, with their anti-canon stance, as lemmings plummeting over a cliff, a flock he dismisses with the label «T he School of Resentment». ${ }^{13}$ Elsewhere Bloom has gone even further and, in a particularly invective piece, has denounced these groups as «a rabblement of false feminists, inchoate would-be-Parisians, and gender-and-power rhapsodes calling themselves $\mathrm{New} \mathrm{H}$ istoricists». ${ }^{14} \mathrm{As}$ overstated as Bloom is in his dismissivness, he has produced in The Western Canon

11. J. AtLAS, op. cit., p. 81.

12. Allan D avid BLO o M, The Closing of the American M ind, N ew York: Simon and Schuster, 1987, p. 379.

13. H arold BLO OM, TheWestern Canon: The B ooks and School of the Ages, N ew York: $\mathrm{H}$ arcourt Brace \& Co., 1994, p. 15, 18 and 4.

14. ID., «W hy N ot Burn Sade?», Bostonia, n. 70, 1996, p. 67-68: 68. 
a well-reasoned and passionate plea for the canon's preservation, emphasizing throughout its literary criteria of value selection, memory preservation and high (read «elitist») aesthetic judgment:

The Western Canon, despite the limitless idealism of those who would open it up, exists precisely in order to impose limits, to set a standard of measurement that is anything but political or moral. I am aware that there is now a kind of covert alliance between popular culture and what calls itself «cultural criticism,» and in the name of that alliance cognition itself may doubtless yet acquire the stigma of the incorrect. Cognition cannot proceed without memory, and the $\mathrm{C}$ anon is the true art of memory, the authentic foundation for cultural thinking. M ost simply, the C anon is Plato and Shakespeare; it is the image of the individual thinking, whether it be Socrates thinking through his own dying, or $\mathrm{H}$ amlet contemplating that undiscovered country. M ortality joins memory in the consciousness of reality-testing that the $C$ anon induces. By its very nature, the Western $C$ anon will never close, but it cannot be forced open by our current cheerleaders. Strength alone can open it up, the strength of a Freud or a $\mathrm{K}$ afka, persistent in their cognitive negations. ${ }^{15}$

Finally, E. D. H irsch, in the phenomenally successful Cultural Literacy, while not specifically addressing the issue of the canon, nevertheless underlines its traditional wisdom in pedagogic circles. Arguing that the education system is in a crisis with long-range social consequences, $\mathrm{H}$ irsch therefore proposes a pragmatic list, ${ }^{16}$ a veritable canon in itself, of what every literate American needs to know in order «to negotiate effectively in the world». ${ }^{17}$ In spite of these spirited defenses, however, the attacks on the canon have had their desired effect. D econstructionism with its canon bashing has become the norm, al ternative canons proliferate and abound and university curricula are replete with «new» courses the likes of which would have been unrecognizable to a student of twenty years ago.

But, although diminished, the canon still survives. N owhere is this more evident than in the case of the canon in Italy both within and outside of its borders. ${ }^{18} \mathrm{O}$ utside, the Italian canon abroad refers to that list of Italian authors

15. ID., The Western Canon, op. cit., p. 35.

16. E. D. HIRSCH, Cultural Literacy: What Every American N eeds to Know, Boston: $\mathrm{H}$ oughton M ifflin, 1987, 1ff. (esp. $27 \mathrm{ff}$ ) and p. 152-215. 0 thers have employed a less pragmatic, but still eloquent plea for the preservation of a core curriculum and have joined it to a spirited defense of the canon. H arry LEVIN («C ore, Canon, Curriculum», CollegeEnglish, n. 43, 1981, p. 352-62), for example, points to a «shared base of knowledge» and a «community od ideas» as the basis of the common intellectual property of educated persons. Without these, he argues, «we will lose our most valued patrimony, our collective memory, and we have seen what wrong turns history can take when it is made by persons and peoples ill versed in it» (p. 362).

17. J. ATLAS, op. cit., p. 91.

18. Romano LUPERINI, one of the scholars most concerned with the Italian canon, has tied the canon closely to literary history ( «La questione del canone e la storia letteraria come ricostruziones, Allegoria, n. 26, 1997, p. 5-13) and has implicity argued for its preservation, 
who have emerged as authoritative figures in the literature, culture and education of non-Italian speaking peoples of the twentieth century. Since, as we shall see, this canon is intimately related to the origins and historical formation of the Italian literary canon, this paper addresses the latter first. In so doing, it will also, hopefully, shed some light on the process of canon formation, that is, on the criteria at work in canon inclusion.

$\mathrm{D}$ ante both begins and looms large over the list of all other members of the Italian literary canon. It is therefore appropriate, as befits his primacy of place, that he, from his privileged position of humble pride, should have given considerable thought to what place he would occupy in the literary canon which would follow him. Any great writer is beset by what $\mathrm{H}$ arold Bloom calls the «anxiety of influence» ${ }^{19}$ and $D$ ante, as a poet, is no exception. In the extraordinary encounter with the poets of antiquity in Inferno 4, the latter, so the narrative goes, welcome him into their illustrious company «si ch'io fui sesto tra cotanto senno» (Inf. 4. 102). W ith this simple gesture, D ante elevates himself to the rank of an auctor, or as we would say today, to the rank of a classic. The gesture is not entirely self-serving. In claiming citizenship in the «bella scola» of «timeless authority», ${ }^{20} \mathrm{D}$ ante also claims legitimacy for the I talian vernacular as a literary language, proclaiming it the equal of Latin, «the grammatical language». In fine, the encounter is an act of cultural self-definition and a bold statement of authorial intention. ${ }^{21} \mathrm{D}$ ante will write (such is his boast) the great Christian epic of conversion (as yet unwritten), and he will do so in Italian, that is, in a language which he is quite literally forging on the spot.

Between aspiration and achievement yawns an abyss. Fortunately D ante's talent matched his ambition. $\mathrm{H}$ is poema sacro was an instant best seller. The literate read it, copied it, and passed it on to friends - the manuscript tradition assures us of this. Those who couldn't read gathered eagerly in public squares to hear the latest news from the other world. The poem was imme diately and widely known, and soon became both an object of study and a source of creative inspiration.

The transition from best seller to classic was almost immediate. By the end of the fourteenth century, D ante's poem had generated more commentaries

drawing up a list of twentieth century Italian authors whom LU PERIN I designates as «Classici», «maggiori» or «grandi» ( «I canone, la scuola el'insegnamento del N ovecento», Alle goria, n. 32, 1999, p. 61-70). In the absence of a clearly defined twentieth century canon by the Italian educational ministry, LUPERINI, in the same aforementioned article, points to the importance of anthologies as preserving the best of Italian «canonical» authors ( $p$. 67 ff.) Similary, Andrea BATTISTIN (op. cit. p. 42 ff.) highlights the importance of an Italian canon, especially in pedagogy, both within Italy and abroad.

19. H. Bloom, The Wetern Canon, op. cit., p. 7-12.

20. Ernst R. CuRTIUS, European Literatureand the Latin M iddle Ages, trans. W illard R. Trask, N ew York: H arper Torchbooks, 1963, p. 18.

21. C fr. Amilcare A. I AN N U CCI, «D ante e la «bella scola» della poesia (Inf. 4. 64-105)», D ante ela «bella scola» della poesia, ed. Amilcare A. Iannucci, Ravenna: Longo, 1993, p. 19-39. 
than Virgil's Aeneid had throughout the whole of the M iddle Ages. It had also engaged the most prominent Italian creative writers of the century, especially Boccaccio and Petrarch. The Comedys impact on the literary scene in fourteenth century Italy was nothing short of phenomenal. Suddenly it was possible to write a great work in the vernacular without having to reach deep into antiquity for models. There was now a contemporary or near contemporary Italian epic in the class of Virgil, Lucan, and Statius (and H omer too) to look up to. D ante was thus emerging as a (vernacular Italian!) canonical poet and an ambitious Italian writer of the time had to come to terms with him and his poem.

H owever, before canonical status can be conferred on any given work, time and acceptance by posterity must intervene. ${ }^{22} \mathrm{Dr}$. Johnson remarked, in reference to Shakespeare's plays, that a century is «the term commonly fixed as the test of literary merit». It is during this period that critical discussion is often most intense with respect to a work's canonical merits and during this period that the same work finds either acceptance or rejection by subsequent and substantial individuals of letters and critics. We see this process at work most acutely in the case of $D$ ante.

The century after $D$ ante's death was marked not only by the rise of a commentary tradition on the poema sacro but also by the appearance of two other Italian writers who would also attain canonical status, Boccaccio and Petrarch. Already by 1400 there were roughly twelve commentaries on the Commedia. ${ }^{23}$ These earliest commentators were driven by one principal practicality, «their wish to make the poem authoritative». ${ }^{24} \mathrm{H}$ owever, as the commentary tradition continued, its main focus changed. A second generation of commentators, beginning with Benevenuto, accepted the authoritative nature of the poem and sought instead, to apply it to particular social questions, to make it, in short, more appealing to particular audiences. ${ }^{25} \mathrm{~W}$ ith the rise of humanism, however, and the advent of the Renaissance, there is a marked shift in the commentary tradition away from an acceptance of the poem as authoritative to a questioning of the poem's authority based on linguistic grounds. «D ante's poem becomes a lightning rod for a host of humanist debates over the poet's impoverished knowledge of classical culture, his historical errors, his linguistic improprieties, and his adherence to a discredited scholasticism and an imperial ideology ${ }^{26}$ Above all else, however, was the issue of $D$ ante's use of a mixed or heterogeneous style for the composition of his poem. The humanists, of course, were committed to the recovery of the classical past. Their aestethics were

22. O $n$ the problematic of «acceptance» for the canon and the fundamental critical importance of the reader, see $\mathrm{H}$ ans Robert JAUSS, op. cit., p. 23-41.

23. D eborah PARKER, «Interpreting the Commentary Tradition to the Comedy», D ante. C ontemporary Perspectives, Ed. Amilcare A. I annucci, Toronto: University of Toronto Press, 1997 p. 240-258 (esp. 241).

24. ID., Commentary and I deology. D ante in the Renaissance, D urham: D uke University Press, 1993, p. 31.

25. Ibid., p. 34-35.

26. Ibid., p. 48. 
driven by the classical ideal of the separation and purity of genres. It should therefore come as no surprise that the Comedys contamination of styles would offend their classical oriented sensibility. Petrarch was one of the first humanists to fault the poem for this deficiency (Familiares 21.15) and he was followed by others such as the great humanist $\mathrm{N}$ iccolò $\mathrm{N}$ iccoli, who was especially persistent in his criticism of D ante, calling him «poeta da calzolai» because of his lowly and popular style. ${ }^{27}$ But as opposed as the humanists were to the poem's hybrid of a style, they were still won over by the poem's lofty subject matter and certainly did not dismiss the work as being unworthy of critical consideration.

The commentary tradition was not alone in being engaged by $D$ ante. Rather, his direct literary heirs, B occaccio and Petrarch reflected deeply on him and were divided in their estimation of him. Boccaccio, D ante's biographer, commentator and great admirer, accepted D ante without hesitation and was totally open to his influence, an influence which we see both in his so-called minor works, the Amorosa Visione especially, and in his major vernacular work. Indeed, in the D ecameron, B occaccio uses D ante to structure and define his very different literary enterprise - the work's subtitle is, you will recall, «Prince Galahalt». O n the other hand, Petrarch refused to read his great predecessor, or so he claims in a celebrated letter to Boccaccio (Familiares 21.15), who had chastised his friend and mentor for his lukewarm attitude towards $D$ ante.

This preoccupation with $\mathrm{D}$ ante by the critical and literary tradition shows that $D$ ante was entering the canonical mainstream. The very same observation can be made of Boccaccio and Petrarch. At the same time, however, the varying assessments of $D$ ante by Boccaccio and Petrarch highlight not only the different literary agendas that almost contemporaneous canonical authors pursue but also the hidden influence that canonical authors have, by virtue of their lofty position, on their literary descendants. In the case of Petrarch, for example, we see how deeply indebted he was to D ante and how he, in spite of his critical observations to the contrary, responded to the «anxiety of influence» by attempting to emulate his literary forebear.

Petrarch's cultural agenda was, of course, much grander than Boccaccio's, consisting of no less than the recovery of classical antiquity, which he felt has been lost, and in the process bringing about a profound renewal of culture, to be based no longer on abstract philosophical schemes but on the studia humanitatis. $\mathrm{H}$ is own fame as a poet and humanist was to be made in Latin, philologically repristined. Thus in his (unfinished) epic, the Africa, he, like D ante, invoked Virgil, Statius, and Lucan (there is also the mandatory nod to H omer), but, in contrast to his famous precursor, he engages them on their own linguistic turf. In this ambitious enterprise to revive contemporary culture, in

27. For a summary of humanistic appraisals of D ante, see D avid THOM PSO N, and Alan F. N AGEL, eds. and trans., The Three Crowns of Florence. H umanist Assesment of D ante, Petrarca and Boccaccio, N ew York: H arper and Row, 1972. 
which he manages to involve Boccaccio, Petrarch was enormously succesfful. Indeed, his reputation and influence during his lifetime and the first threequarters of a century or so after his death were based almost entirely on his Latin, humanistic compositions. D uring this period, Boccaccio too was known less for his vernacular writing than for his classical scholarship, to which, under the sway of Petrarch, he dedicated the latter part of his life. $\mathrm{H}$ is encyclopedic Genealogia deorum gentilium, for instance, became a standard reference text throughout Renaissance Europe.

Petrarch, however, was much too sensitive to literary history to ignore the vernacular completely, despite his apparent scorn for it. We know the care that went into the making of the Canzoniere which he refers to simply as Rerum vulgarium fragmenta. And although he stakes his ultimate fame on the Africa, he is not about to hedge his bets. H e informs us in another celebrated letter to Boccaccio (Seniles 5.2) that from an early age he had planned to write a «great work» (magnum opus) in the vernacular, a probable reference to the Triumphs. Written in terza rima in obvious competition with $D$ ante, this little work became the source (about the middle of the fifteenth century) of a second wave of Petrarchan influence in Europe. The first, as I have already noted, was driven by his Latin works; the third and last in chronological order would be fuelled by the Canzoniere ${ }^{28}$

These waves of Petrarchan influence testify to another important aspect of canonical inclusion. As Alastair Fowler ${ }^{29}$ points out, «changes in literary taste can often be referred to reevaluation of genres that the canonical works repre sent». N owhere is this more evident than in the case of Petrarch, less so of Boccaccio and D ante. After the initial success of Petrarch's Latin works the Triumphs then achieved wide-spread acceptance and exerted incredible influence. In the latter half of the Q uattrocento, the Triumphs surpassed even D ante's C ommedia in popularity, and remained a powerful literary force well into the seventeenth century. $\mathrm{H}$ undreds of surviving manuscripts scattered throughout Europe attest its remarkable diffusion, and after the first Venetian edition of 1470, it was reprinted regularly. M oreover, during this time it was repeatedly illuminated, glossed, translated, and generally revered. The source of a rich and extensive iconographical tradition which soon took on a life of its own, it also left its imprint on Renaissance pageantry and spectacle. Even more enduring, however, was the later success of the $C$ anzoniere. $O$ riginating in Italy near the end of the fifteenth century, it spread quickly throughout Europe, to France, Spain and England. The channels of diffusion were many and diverse, but the end result was that Petrarch (directly or indirectly) defined the vocabulary of a lover's discourse, no matter what language he spoke. $\mathrm{H}$ is work was so thoroughly assimilated into the various European national literatures that he has become

28. H atch Ernest WILKIns, Studies in the Life and Works of Petrarch, Cambridge, M ass.: M edieval Academy of America, 1955, p. 280-281.

29. Alastair Fow LER, Kinds of Literature. An Introduction to the Theory of Genres and M odes, Cambridge, M ass.: H arvard U niversity Press, 1982, p. 214. 
an integral part of these literary traditions, at least in the lyric sphere. Thus, while never losing canonical status, certain Petrarchan genres were more important to the literary tastes of some ages than others. It is an irony, often noted, that the greatest Latinist of the Trecento should have become a classic of world literature principally for his works in the vernacular. ${ }^{30}$

By the beginning of the sixteenth century over a century of critical appraisal and, more often than not, general and literary acceptance had been bestowed on the works of $D$ ante, Boccaccio and Petrarch. It remained a formality for Bembo to canonize the three great Florentine poets in his Prose della volgar lingua, the first work, incidentally, on Italian grammar. To be sure, Bembo too had serious reservations about $D$ ante. H owever, the author of the Commedia had survived all literary onslaughts and imposed himself with such literary weight that he could not be excluded. But the canon was not yet complete, for after the humanistic hiatus of the Q uattrocento, I talian literature continued to flourish in the sixteenth century, producing at least three more figures of canonical stature. I refer to Ariosto, ${ }^{31}$ Tasso and, in a slightly different category, M achiavelli. That is not to say that other Italian authors of the period did not have a major impact on European culture. O ne has to look no further than Bembo himself, who played such a pivotal role in the European diffusion of Petrarch and Ficinian N eoplatonism, for an example. The distinction I make here, of course, is between those authors whose impact, although significant, is limited in time and space, and those whose influence is enduring and universal. From this perspective, and let this one example suffice, Bembo and Petrarch are worlds apart. H owever that may be, there is little doubt that by the end of the sixteenth century the Italian literary tradition as a whole had acquired, in the eyes of the rest of Europe, a status similar to that of the great literatures of G reece and Rome, which had been revived on Italian soil and, in large part, by I talians. But it was also at about the same time that I taly's literary prominence started to decline. The cultural center now shifted northwards beyond the Alps to France and England and westwards to Spain. Later it would extend to Germany, and Russia too. I taly's cultural hegemony was at an end; more ideas now flowed into Italy than out.

To be sure, Italy did not stop producing exportable literature in the centuries after the Renaissance. $O$ ne need only think of $\mathrm{M}$ arino and his prominent place in the European Baroque, or Goldoni and the popularity of the commedia del'arte in eighteenth century France, or on a wider stage, the influence of Vico's thought, especially in the twentieth century. The delayed reception of Vico is an interesting case, and I shall return to it in a moment. O ne could, of course, multiply the examples in the centuries following the Renaissance of Italian authors who enjoyed a measure of success abroad - Alfieri,

30. Thomas Goddard Bergin, Petrarch, Boston: Twayne Publishers, 1970, p. 146.

31. For an account of the elevation of Ariosto to canonical status, see D aniel J AVITCH, Proclaiming a Classic: The Canonization of «O rlando Furioso», Princeton: N . J., Princeton University Press, 1991. 
Foscolo, Verga, and so on. But their influence was never as formative abroad as that of the canonical authors listed above. Even the two acknowledged masters of Italian Romanticism, Leopardi and M anzoni, never found the consensus and widespread influence to enter the type of literary canon that I am here detailing. T hus, while there are many authors who are part and parcel of the Italian national canon, it is the canon of D ante, Petrarch, Boccaccio, Ariosto, Tasso, M achiavelli, and Vico (with the possible addition of Pirandello which is an exception to which I shall return) that has had an enduring effect on the literary culture of our time. They have remained powerful cultural forces to this day, often the focus of intellectual and academic debates and the source of creative inspiration. In the battle between the ancients and the moderns, the former seem to have prevailed. In what follows I shall attempt to justify this generalization by focusing on the reception of Italian literature in the twentieth century. I shall therefore explore the extent to which Italian literature in this century is a) studied abroad; b) has been and continues to be translated; and c) seriously engages contemporary non-I talian writers.

$O$ ver the last century and especially since the Second World War, the study of I talian literature abroad, which is confined almost exclusively to the university curriculum, has expanded enormously. There are now more teachers, students, and journals of Italian Studies than ever before. ${ }^{32}$ In N orth America the magnitude of Italian Studies is enormous. M ost major universities have at least one Italianist on staff, and many have developed a well-articulated program leading to a degree in Italian. In large centers, such as the U niversity of Toronto, the whole of the Italian literary tradition from St. Francis to the present is invoked and taught in the original language. Elsewhere, however, this is often not the norm and Italian studies are skewered towards authors of the Italian canon abroad and are taught in translation. Of these authors $D$ ante is the dominant force, especially at $\mathrm{H}$ arvard where the $\mathrm{D}$ ante Society of America was founded in 1881 and where there is a long and prestigious tradition of D ante studies, stretching from Ticknor and Longfellow through to Lowell and N orton and into the twentieth century with Grandgent and Singleton. In addition, $\mathrm{D}$ ante is often taught by a variety of departments, other than Italian, in translation. O ne example, close to home, shall suffice, namely, the University of Toronto, where $D$ ante is taught in English translation by M edie val Studies, Christianity and Culture, Literary Studies, the D epartment of English, and Comparative Literature.

32. All of this is documented in the proceedings of several recent conferences on the subject, including one at the Sorbonne in 1987 on Italian journals (Les revues italianistes dans le monde published in Revue des études italiennes, ns. 34.4, 1988) and another, held in Perugia in 1988, on the diffusion of Italian language and literature throughout the world (Lingua e letteratura italiana nel mondo oggi). The latter was sponsored by the Associazione Internazionale per gli Studi di Lingua e Letteratura Italiana, which has done much to promote Italian language and literature abroad since its founding in 1950: see V ittore BRAN $C A$, «R elazione introduttiva», Lingua e letteratura italiana nel mondo oggi, eds. I gnazio BALDELLI, and Bianca M aria D A RIF, Firenze: O Ischki, 1991, vol. 1, p. 6-11. 
O bviously, D ante is a special case, but a similar story can be told of Italy's other classic authors: Petrarch, Boccaccio, M achiavelli, Ariosto and Tasso. These authors too are taught more in translation than in the original - Petrarch in courses on lyric poetry, Boccaccio in genre courses, M achiavelli in history and political science courses, A riosto and Tasso as epic precursors to Spenser and M ilton - and all of them in popular Renaissance study programs and great books course. Boccaccio and $M$ achiavelli have especially captivated the American imagination. The American Boccaccio Association publishes a Boccaccio $\mathrm{N}$ ews etter and sponsors a regular lectura Boccaccii. As for $\mathrm{M}$ achiavelli, his American profile is one of intrigue and ambiguity: a serious object of study in academe with a journal in his name, M achiavelli Studies; a ruthless villain or sweet seducer in popular culture, depending upon whether the referent is T he Prince or the $\mathrm{M}$ andragola. In his latter persona, his name, slightly al tered, has become a perfume, Prince $M$ atchabelli. But Petrarch too continues to be a formidable presence in the American university curriculum and hence in the cultural and literary life of the country.

I pointed out earlier that Petrarch's far-reaching influence in the Renaissance was attributable to three separate components of his vast production: his humanistic Latin works, his I talian lyric poems and the Triumphs. The latter work, which once vied with Dante's Comedy for cultural supremacy, has today been almost completely forgotten. $\mathrm{H}$ owever, it is precisely in $\mathrm{N}$ orth America that it is now in the process of being re-evaluated. At a recent conference on the work, Petrarch's Triumphs. Allegory and Spectacle, the question was asked: «W hy does $D$ ante's «medieval» Commedia continue to be contemporary while Petrarch's competing «modern» poem has, despite its virtues, become archaic?» Since the question invokes such complex issues as textuality, literary taste, and patterns of transmission and influence, no easy answer emerged. It was noted, however, that had Petrarch remained locked in D ante's vision, language, and signifying system, the Triumphs would not have had its moment of glory and the Renaissance might have taken a different course, so determining was Petrarch's role in fashioning the period. ${ }^{33}$

Translations too are biased in favor of the authors of the Italian canon abroad. O nce again, D ante is the principal focus. In the Anglo-American world the situation is extraordinary. Here even D ante's so-called minor works have been transated several times in the twentieth century, the Vita N uova in particular, but also the Convivio. Indeed, two new English versions of the Convivio appeared within a year of each other in the U nited States, 1989 and 1990. As for the Commedia, it has become the custom for prominent American D antists to crown their careers with a translation of the poem (Longfellow, N orton, Bergin, Singleton, M usa). Similarly, talented professional translators ( $M$ andelbaum) and poets (C iardi, Pinsky) have come to see the poem as a measure of their skills.

33. Amilcare IAn N U CCl, «Foreword», Petrarch's Triumphs. Allegory and Spectacle, ed. Konrad EISEN BICH LER and Amilcare A. I AN N U CCI, O ttawa: D ovehouse, 1990, p. xi-xV. 
After $D$ ante, it is the other authors of the Italian canon abroad who have kept the translators busiest. A few statistics, again from the Anglo-American scene, will illustrate this point: Petrarch's Canzoniere has been translated at least five times in the past century while the D ecameron has provoked four translations; despite the frequent reprintings of Sir John $\mathrm{H}$ arrington's famous Elizabethan translation (1591) of the O rlando Furioso and that of W illiam Stewart Rose (1831), the poem has been completely re translated by Barbara Reynolds (1975) for Penguin C lassics; Tasso's Jerusalem D elivered has been translated anew twice, although Edward Fairfax's splendid translation in English octaves still reigns supreme; $M$ achiavelli's Prince, D iscourses, and M andragola have all been translated more than once.

$\mathrm{N}$ ext, I would like briefly to describe the extraordinary case of the interesting phenomenon of an author and a book that were catapulted to the status of a classic, in part on the basis of a translation. I am, of course, referring to Vico and the Scienza N uova. Largely unknown in the English-speaking world, despite J oyce's admiration for and use of V ico, until Bergin and Fisch's 1948 translation for Cornell U niversity Press (the two had al ready translated Vico's autobiography in 1944), the N ew Science has now become a powerful cultural force. Its influence reaches far beyond the boundary of literature and literary theory (in this Vico is in the same category as M achiavelli), extending into the various branches of cognitive science and philosophy. In addition to Joyce, Vico's thought has had a profound influence on the work of $M$ arshall M CLuhan and N orthrop Frye (both of the U niversity of Toronto), two of the most cited authors of the twentieth century. The «American» Vico has become almost as important as the I talian one, whose convoluted prose has al ways posed a problem. In 1974 G iorgio Tagliacozzo founded the Institute for Vico Studies in N ew York City, which since 1983 has published the influential journal N ew Vico Studies. As with Dante, America has appropriated Vico and it now generates at least as much critical literature on him as does Italy.

Perhaps the ultimate measure of the impact of old Italian literature is the degree to which it has managed to influence, in a formative way, the major authors of other literary traditions. Certainly, this is the most profound and enduring form of its reception because it has left a permanent record of the transaction - a new text capable of transmitting further its Italian source. In 1929 T. S. Eliot declared that «D ante and Shakespeare divide the modern world between them». ${ }^{34}$ In his preface to D ante Among the M oderns, Stuart $Y$. $M$ CD ougal adds that «D ante's impact on the major writers of the modern world has far exceeded that of Shakespeare». ${ }^{35}$ And perhaps that influence is nowhere stronger than in the work of the major British and American modernists, a group that includes W. B. Yeats, James J oyce, Ezra Pound, T. S. Eliot, Samuel Becket, W. H. Auden, and Wallace Stevens. Joyce's indebtedness to

34. Thomas Stearns EliOT, D ante, London: Faber and Faber, 1929, p. 51.

35. Stuart Y. M CD o u GAL, «Preface», D ante Among the M oderns, ed. Stuart Y. M CD ou GAL, Chapel H ill: University of N orth Carolina Press, 1985, p. IX-XIII: IX. 
D ante is well known and well documented. ${ }^{36} \mathrm{D}$ ante is his favorite author and engagement with the Florentine poet extends over a lifetime. $D$ ante's presence al ready permeates D ubliners (1914); it informs the structure of «G race» and haunts the pages of «T he D ead». This intertextual dialogue continues at various levels in the Portrait of the Artist asa Young M an (1916) and especially in U lys ses (1922), and culminates in Joyce's audacious experiments with language in Finnegan's Wake (1939), which he licenses by appealing to the incipit of Inferno 7: «Pape Satàn, pape Satàn aleppe!»

Although the nature of $D$ ante's influence varies from author to author, in all of the modernists listed above it is a lifelong engagement. This is especially the case with Eliot, of course, but with Pound too, whose Cantos (portions published in 1925, the first complete English edition of all segments in 1970), written over a period of fifty years, Kenner has called his «C ommedia». ${ }^{37}$ It is also the case with Becket, although as Wallace Fowler has noted, after the poem «M alacoda» in Echo's Bones (1935) and the opening story of M ore Pricks Than Kicks (1934) entitled «D ante and the Lobster» and featuring a protagonist with the odd name (for an I rishman) of Belacqua, «specific allusions to D ante are very infrequent in Becket's work». ${ }^{38}$ Yet, if anything, D ante's presence in the later Becket is more pervasive and significant, but also more subtle and difficult to define. It expresses itself elusively - more in tone and perspective than overt thematic parallels. Certainly, Waiting for G odot (1949) has a D antesque fed to it.

The other authors of the Italian canon abroad have likewise left their mark on literature outside Italy. The sixteenth century English poet, Thomas Wyatt for example, translated and freely adapted into English various verses composed by Petrarch. Three centuries later, Walter Savage Landor, in T he Pentame ron (1837), used Petrarch and his literary contemporary Boccaccio to drive the imagined literary conversations between the two over a five-day period. But it was Petrarch's Triumphs and Canzoniere, as I have pointed out above, that were destined to win for him the widest possible imitation. N ot only did Renaissance translations of the Triumphs advance vernacular languages to new positions of authority but the work had a decided impact on European drama, especially in France and Spain. W ith respect to his love sonnets, «t has been calculated that over three hundred thousand short lyrics, mostly sonnets, were written in the sixteenth century in Europe and that the majority of them were direct imitations of Petrarch's»).39 Thus, influenced by the Canzoniere, poets such as the members of the Pléiade in France, especially Ronsard with his Amours de Cassandre(1552), and C amoëns in Portugal, idealized in their poems the emotion of love while Sir Philip Sydney established the Petrarchan sonnet

36. Cfr. M ary T. Reyn o LDS, Joyce and D ante: The Shaping Imagination, Princeton, N . J.: Princeton University Press, 1981.

37. Hugh K En N ER, «Ezra Pound's Commedia», D ante Among the M oderns, op. cit., p. 39-56.

38. Wallace Fow LER, «D ante and Becket», D ante Among the M oderns, op. cit., p. 128-152: 143.

39. Francesco GUARDIAN I, «The Literary Impact of the Trionfi in the Renaissance», Petrarch's Triumphs. Allegory and Spectacle, op. cit., p. 259-268: 259. 
form in England with his sonnet sequence Astrophel and Stella (1591). Still later, Petrarchan influence can be seen in Elizabeth Barrett Browning's Sonnets from the Portugese (1850) and it is the Petrarchan love sonnet that has left its mark on practitioners of modern versification such as Edwin Robinson, Elinor Wylie, Edna St. Vincent M illay and W. H. Auden. Boccaccio's influence stretches from Chaucer, whose Canterbury Tales uses The D ecameron's frame story device and whose Knight's Tale is an abbreviated version of Teseida, to authors of the present day. Among myriad works affected by him, we may cite the Tales and N ovels in Verse (1667-74) and the Fables (1668-94) of La Fontaine, the plays L'école des maris (1661) and G eorge D andin (1668) of M olière, La Discreta Enamorada (1606) of Lope de Vega and Cymbeline (1610?) and All's Well that Ends Wel (1602?) by Shakespeare ${ }^{40}$ Above all else, the master story teller of the $D$ ecameron has made a lasting impression on authors who delight in the strange, the absurd and the picaresque. These were the characteristics that endeared Boccaccio to D ryden who wrote metrical paraphrases of him, among others, in his Fables Ancient and M odern (1699), and among Boccaccio's more modern followers, we may mention the master story tellers of the nineteenth century, Alphonse D audet and Guy D e M aupassant, and those of the twentieth, John Cheever, W illiam Trevor, Raymond C arver, M avis G allant, and Alice M unro.

Both Ariosto and Tasso ${ }^{41}$ have played a formative role in literature outside of Italy. They both, for example, influenced the shaping of English epic. Spenser's allegory was modeled on that of Ariosto ${ }^{42}$ whom he set out «to overgo» and the English poet «imitated phrases, verbal patterns and knightly images» from not only Ariosto's 0 rando Furioso but also Tasso's G erusalemme liberata. ${ }^{43}$ M oreover, John M ilton set Tasso alongside Virgil and $\mathrm{H}$ omer as the great models for the epic and his Paradise Lost is closest to Tasso in diction and style ${ }^{44} 0$ ther European poets affected by the two include Cervantes «who is perhaps the closest of any of Ariosto's admirers to his subtle irony ${ }^{4},{ }^{45}$ La Fontaine who composed three verse tales modeled on episodes in the Furioso, D ryden, who shared with Tasso close sensibilities, so that individual scenes such as the Enchanted Wood

40. The influence of Boccaccio, from a literary comparative point of view, was first explored in English by Charles Cushing in an article he wrote for The N orth American Review. For this article and its place in Boccaccio criticism, see Alfred O wen ALBRIDGE, «T heFirst American Interpetetion of Boccaccio», II Boccaccio nella cultura inglese e anglo-americana, ed. Giuseppe G ALIANI, Firenze: O Ischki, 1974, p. 219-230.

41. C. P. BRAN D, Ludovico Ariosto. A Preface to the O rlando Furioso, Edinburgh: Edinburgh University Press, 1974; ID., Torquato Tasso. A Study of his C ontribution to English Literature, C ambridge: Cambridge University Press, 1965 and Andrea Buzzo NI (ed.), Torquato Tasso tra letteratura musica teatro e arti figurative, Bologna: N uova Alfa Editoriale, 1985.

42. Susannah Jane M CM URPHY, Spenser's U se of Ariosto for Allegory, Folcroft Pa, Folcroft Press, 1969.

43. Andrew SAn DERS, The Short 0 xford H istory of English Literature, 0 xford: 0 xford University Press, 1994, p. 128.

44. C. P. BRand, Torquato Tasso, op. cit., p. 251-252.

45. ID., Ludovico Ariosto, op. cit., p. 191. 
in King Arthur (1691) are imbued with Tassessque atmosphere, and Byron, who used the story of Tasso's supposed love for the princess Leonora (immortalized in Goethe's play Torquato Tasso [1790]) as the basis of his Lament of Tasso (1817). But perhaps, the influence of both Ariosto and Tasso is best seen in the Spanish literary tradition, first on native soil and then in those countries colonized by Spain. Both made a deep impression on the writers of Spain's G olden Age, especially in the areas of epic and lyric poetry and drama. Central of course, to Cervantes' D on Q uixote (1605-1615) is a character whose madness is pitted against the external world. Both this aspect of the central character as well as the pomp and imagery associated with him are derived from A riosto. M oreover, the erudite epic La hermosura de Angélica (1602) by Lope de Vega, which was composed while he was aboard a galley of the ill-fated Armada, was a continuation of the 0 rlando Furioso. The same female character from Ariosto inspired another epic by D e Soto, Laslagrimas de Angélica (1586). M oreover, Ariosto influenced a host of lyric poets such as G óngora, Fray Luis de León, G arcilaso (a favorite strophe of the latter two was the lira which came from Ariosto) and Juan Boscán who naturalized to Spain the octaves of the Italian poet. Finally, playwrights such as Lope de Vega turned frequently to Ariosto and Tasso for dramatic subjects as the plays Celos de Rodomonte (1588), Angélica en el Catay (1600) and Jerusalen conquistada (1609) amply bear witness. In addition to these exclusive products of the Spanish mainland, both Ariosto and Tasso also influenced works from Spain's colonial world. The sixteenth century Spanish poet, Ercilla, for example, who had participated in the conquest of $C$ hile, used both Ariosto and Tasso for the shaping of his epic Araucana (1569-89) and in the same century one of the first Peruvian poets, D iego de H ojeda, composed his vast poem on Christ, Christada (1611), under the sway of both Ariosto and Tasso. In the following century, in what is considered to be Cuba's first poem, Espejo de paciencia (1608), Silvestre de Balboa has reminiscences of both Ariosto and Tasso mediated through Italianate Spanish poets such as D e Soto. Ariosto and Tasso have continued to influence the Spanish-American tradition in the modern period. They have, for example, contributed to the poetic imagery of $O$ ctavio Paz with its concentration on beauty and individual communication with the external world and they have colored the weaving of real ism and fantasy that is the hallmark of the works of G abriel García M árquez. M ost importantly, they have played a decisive role in the shaping of the literary vision of Jorge Luis Borges. References to both authors abound in his works ${ }^{46}$ and Borges shaped many of his pieces in response to their influence. A prime example is Borges' long poem «Ariosto y los árabes». H aving come to A riosto almost by chance, Borges was fascinated that this poet, once revered as among the greatest in the sixteenth and seventeenth centuries, had fallen into almost total neglect in more recent time. The key to this neglect for Borges lay in A riosto's,

46. A useful index of all references of Borges is provided by Daniel BALDSERSTON, The Literary U niverse of Jorge Luis Borges. An Index to Reference and Allusion to Persons, Titles, and Places in H is Writnigs, N ew York: Greenwood Press, 1986. 
and thus, the poet's, vision, which is fleeting and subject to the whims of time. Accordingly, Borges uses this (both Ariosto's and his) vision to fuel his poem which extols and exalts Ariosto's fantasy.

$M$ achiavelli's influence can be seen in the Elizabethans, such as $M$ arlowe, Kydd and perhaps Shakespeare himself, ${ }^{47}$ some of whose characters, such as $\mathrm{K}$ ing $\mathrm{Claudius}$ in $\mathrm{H}$ amlet suggest $\mathrm{M}$ achiavellian underpinnings, the $\mathrm{G}$ erman Romantics, and the American pastoralists. Perhaps, however, his greatest influence has been on contemporary literature. Pound, for example was deeply indebted to him. H e heads the memoir of his dead sculptor friend, G audier-Brzeska (1916) with a quotation from M achiavelli and his defense of Italian politics, together with its apparently shocking juxtaposition of Jefferson and M ussolini in the Cantos, is due to Pound's reading of M achiavelli's conception of power and the place in it of virtù. ${ }^{48} \mathrm{M}$ oreover, M uriel Spark has imbued all of her novels with a $M$ achiavellian feel. This is especially true of The Comforters (1957), The Girls of Slender M eans (1963), and The Prime of M iss Jean Brodie (1961), about an eccentric Edinburgh schoolteacher who manipulates, but is greatly admired by her pupils. This preoccupation continues in Loitering with Intent (1981), a discussion of good, evil, and the writer's mind. Perhaps, howe ver, the M achiavellian influence is most apparent in the Abbess of Crewe (1974) in which the artful and cunning religious superior gleefully mingles for her charges passages from $M$ achiavelli within a wide range of poetic references. The case of Vico, as pointed out above, is an exception and the diffusion of Vico's Scienza N uova was, until this century sparse. This is strange and V ico, whose ideas were remarkably similar to the G erman pre-Romantic and Romantic writers, «should have been one of their acknowledged and admired forerunners», as Auerbach notes, ${ }^{49}$ but was not. Even G oethe failed to recognize his importance. Auerbach sees this failed reception as «one of the most astonishing facts in the history of ideas». But even in Italy, «nobody really understood his ideas».50 For almost two hundred years the Scienza N uova was very much a text in search of a comprehending reader. It finally found two, Croce and J oyce. H owever, it was primarily through the latter that it found an international audience. M cLuhan was a great admirer of Joyce, especially the Joyce of Finnegan's Wake. It was there that M CLuhan discovered Vico, whom he was able to read because of the Fisch-Bergin translation. M CL uhan pays his debt to the $\mathrm{N}$ eapolitan writer in his last book, published posthumously by his son, the L aws of the M edia. It is subtitled The N ew Science.

These then are the authors who have a predominant place in the spreading of I talian literature abroad. By contrast, other I talian authors do not have the

47. Edward Stockton M EYER, M achiavelli and the Elizabethan D rama, Weimar: E. Felber, 1897.

48. Reed Way D ASEN BRo ck, Imitating the Italians. Wyatt, Spenser, Synge, Pound, Joyce, Baltimore: The Johns H opkins University Press, 1991, $158 \mathrm{ff}$.

49. Erich AuERBACH, «Vico and the Aesthetic H istorism», Scenes from the D rama of European Literature, New York: M eridian Books, 1959, p. 183-198: 189.

50. Ibid., p. 187-189. 
same importance, not even the canonical ones of the nineteenth and twentieth century, who are listed in Bloom's V ician inspired C haotic Age.51 The sole exception is Pirandello who is widely taught (he is the only one who also has a society, the Pirandello Society and a journal, Pirandellian Studies in America), is commonly translated, ${ }^{52}$ and is at the center of a formative and massive literary influence that stretches from Brecht to Sartre and beyond. ${ }^{53}$ Thus, in the future Pirandello may have to be added to the other authors of the Italian canon abroad. In a similar vein it is the test of time that will determine the inclusion or not of I talo Calvino whose late works (II castello de destini incrociati, Se una notte d'inverno un viaggiatore, Palomar) have received high literary praise and which appeal to a more refined, intellectual audience, and U mberto Eco who has enjoyed both critical and popular success. The latter author, in fact, is an excellent example of the pragmatic business of the process of canon formation, and, as such, deserves a brief excursus.

The reasons for the phenomenal success of the $\mathrm{N}$ ame of the Rose (its marketing and its exploitation of Eco as a cultural figure) have been thoroughly documented. ${ }^{54}$ In addition, the internal - textual - reasons for its success have not been neglected. When the novel first appeared, the general consensus, in fact, was that Eco had succeeded in writing the kind of work hypothesized in Apocalittici e integrati, 55 that is, an open and closed text, capable of reaching a large audience from simple readers to more sophisticated ones who were eager to participate in the novel's complex allegorical discourse. Thus, it is important to note that II nome della rosa was being reviewed and talked about in critical parameters set by Eco himself. In addition, Eco, realizing that canonical status is only conferred on a work which is an object of academic and critical study, took steps to ensure that his work would become a classic. Accordingly, he published Postillea «ll nome della rosa» in the June 1983 issue of Alfabeta, situating the work securely within the debate on the postmodern, and in 1985 his publisher, Bompiani, published a collection of 35 essays, Saggi su «| nome della rosa», written by scholars from all over the world and edited and

51. Cfr. H. Bloom, The Western Canon, op. cit., Appendix A. Bloom's canon of Italian authors, divided across $V$ ico's four ages (theocratic, aristocratic, democratic and chaotic) is simply a list (albeit with a separate chapter on D ante) of definitive Italian writers. For a much more exhaustive list of I taly's national canon throughout the ages, accompanied by critical discussion, see Peter BRAN D and Lino PERTILE, The Cambridge H istory of I talian Literature, Cambridge: Cambridge University Press, 1996.

52. A. I AN N U CCI, «T he Presence of Italian Literature Abroad (O Id and N ew) Abroad in the Twentieth Century», Italian Studies in N orth America, ed. M assimo Ciavolella and A. Iannucci, 0 ttawa: D ovehouse Editions, 1994, p. 17-54: 34-36.

53. Ibid., p. 36-38.

54. See Gian Carlo FerRetTI, II best-seller all'italiana: fortuna e formule del romanzo di «qualità», Bari: Laterza, 1983; ID., La fortuna letteraria, U rbania: Transeuropa, 1988; several essays in Renato G Iovan o Llı (ed.), Saggi su «I nome della rosa», M ilano: Bompiani, 1985; most recently M argherita G AN ERI, II nome della rosa. U na strategia di successo, C osenza: Grisolia Editore, 1990 and ID., II «caso» Eco, Palermo: Palumbo, 1991.

55. U mberto Eco, Apocalittici eintegrati, M ilano: Bompiani, 1964. 
introduced by Renato Giovannoli. M oreover, not only critical glosses were afforded II nome della rosa. N o fewer than 31 artists took up the challenge of illustrating the nove ${ }^{56}$ and prominent French director, Jean-Jacques Arnaud turned the novel into a heavily financed film starring Sean C onnery, a film which, unfortunately did not have the success of the novel and which opened to mixed reviews. ${ }^{57}$ T hus, like D ante's Commedia E co's Rose was almost immediately deemed worthy of the deepest critical respect, both literary and artistic, and Eco emerged as one, who, like $D$ ante before him, by his bold act of self-inclusion in the «fair school» of poetry in Limbo, was offering himself for canonization.

The negotiations for canonical status are complex. The canonization of the authors of the Italian canon abroad (with the exception of Vico and perhaps $\mathrm{M}$ achiavelli) began during their own lifetimes. And their response to the challenge was critical to their ultimate elevation. D ante, Petrarch, Boccaccio, Ariosto, and Tasso - in addition to writing literature, they all wrote about literature, and managed to place themselves at the center (as Eco has done) of the literary debates of their times. In the end, however, the designation «canonical» has stuck to their works because of their textual properties: their energy, adaptability and translatability. These qualities have assured them large audiences throughout history, both within and, especially, outside Italy. Whether or not, T he N ame of the Rose, has the textual characteristics to guarantee it the staying power required for canonical status, only time and ongoing literary appeal will tell.

The authors of the Italian canon abroad are not dead authors, but are forever alive and vibrant, both within and, especially, outside of Italy. They continue to form the minds of thousands of students, continue to bring pleasure and profit to the reading public and continue to influence the literary currents of the day. In an age which is so concerned with the preservation or not of the literary canon, they, even apart from that canon, are both witness and testimony to the far-reaching diaspora of I talian literature abroad. In so doing, they are, in the end and ultimately, a powerful reminder that, in spite of all of the polemic debates centered on the canon, great literature and the literary criticism it engenders will not die, but will continue to bring pleasure to all those outside of I taly's borders who come into contact with the very best that the Italian language has to offer.

56. La rosa di pinta. Trentuno illustratori per «l nome della rosa» di U mberto Eco, M ilano: Azzurra editrice, 1985.

57. A. IAN NUCCI, «T he Presence of Italian Literature», op. cit., p. 41. 